\title{
Dietary Combination of Fish Oil and Hemoglobin Hydrolysates Alters Serum and Liver Lipid Contents in Rat
}

\author{
Kenji Fukunaga $^{{ }^{*}}$, Noriko Yukawa ${ }^{1}$, Ryota Hosomi ${ }^{2}$, Toshimasa Nishiyama ${ }^{3}$, Munehiro Yoshida ${ }^{1}$ \\ ${ }^{1}$ Department of Life Science and Biotechnology, Faculty of Chemistry, Materials and Bioengineering, Kansai University, Suita, Ja- \\ pan; ${ }^{2}$ Division of Food Science and Nutrition, Tottori College, Kurayoshi, Japan; ${ }^{3}$ Department of Public Health, Kansai Medical \\ University, Hirakata, Japan. \\ Email: *fukunagk@kansai-u.ac.jp
}

Received May $12^{\text {th }}, 2013$; revised June $12^{\text {th }}, 2013$; accepted June $19^{\text {th }}, 2013$

Copyright (C) 2013 Kenji Fukunaga et al. This is an open access article distributed under the Creative Commons Attribution License, which permits unrestricted use, distribution, and reproduction in any medium, provided the original work is properly cited.

\begin{abstract}
Fish oil has been shown to have anti-inflammatory and anti-cancer effects, and to reduce serum triacylglycerol (TAG) levels by stimulating lipid oxidation and inhibiting lipogenesis in the liver. A small number of studies have demonstrated the synergistic effect of fish oil and other bioactive components. This study examined the effect of fish oil in combination with porcine hemoglobin $(\mathrm{Hb})$ hydrolysates on serum and liver lipid contents in rats. Male Wistar rats were divided into four groups; one group was fed a casein and soybean oil-based semi-purified basal diet and other three groups were fed the basal diet supplemented with $2 \%$ fish oil, $0.175 \%$ Hb hydrolysates, and $2 \%$ fish oil plus $0.175 \% \mathrm{Hb}$ hydrolysates, respectively, for 4 weeks. The fish oil diet decreased serum and liver TAG contents but did not change serum and liver cholesterol levels. The dietary combination of fish oil and $\mathrm{Hb}$ hydrolysates decreased serum and liver TAG and cholesterol contents owing to the additive effect of both compounds, and this diet reduced the serum non-high-density lipoprotein cholesterol content as a result of a synergistic effect. This hypolipidemic effect was in part caused by enhanced excretion of fecal fatty acids, neutral steroids, and acidic steroids. The results of this study suggest that the combined intake of fish oil and $\mathrm{Hb}$ hydrolysates may play beneficial roles in the prevention of cardiovascular disease as compared with fish oil alone.
\end{abstract}

Keywords: Fish Oil; $n$-3 Polyunsaturated Fatty Acid; Hemoglobin Hydrolysates; Lipid Metabolism

\section{Introduction}

Epidemiological studies have suggested that the consumption of seafood can prevent cardiovascular disease (CVD) [1]. In particular, the health benefits of seafood have principally been associated with high intakes of $n-3$ polyunsaturated fatty acids (PUFAs), eicosapentaenoic acid (EPA) and docosahexaenoic acid (DHA) [2]. Fish oil contains high levels of EPA and DHA and is sold as a functional food that can promote superior health. Dietary fish oil has been linked to preventing arrhythmia [3], decreasing triacylglycerol (TAG) by stimulating fatty acid $\beta$-oxidation, and inhibiting fatty acid synthesis in the liver [4]. These beneficial effects of $n-3$ PUFAs involving reduction of TAG and enhancement of anti-inflammation, membrane fluidity, anti-arrhythmic and antithrombotic effects mediated protection against CVD as a

${ }^{*}$ Corresponding author. result of multifaceted synergistic processes [5]. A previous systematic review of randomized controlled trials demonstrated that dietary $n$-3 PUFAs decrease serum TAG levels but did not lower serum cholesterol content [6]. Several clinical trials have evaluated whether the combination of $n$-3 PUFAs and statin, a 3-hydroxy-3methylglutaryl coenzyme A reductase inhibitor, improved the lipid profile, mainly cholesterol levels, in hyperlipidemic patients $[7,8]$. Saify et al. suggested that the combined administration of fish oil and lovastatin (Mevacor $^{\mathbb{B}}$ ) result in a significant reduction in high-density lipoprotein (HDL)-cholesterol content compared with fish oil treatment alone [7].

Fish oil has also been reported to exhibit a synergistic effect with other bioactive components in food. For example, dietary fish oil with added sesamin enhanced hepatic fatty acid oxidation [9], conjugated linoleic acid attenuated fatty liver [10], fucoxanthin suppressed weight 
gain of white adipose tissue (WAT) [11], and taurine decreased fat accumulation and ameliorated blood glucose level [12]. Our previous study showed that the simultaneous dietary administration of fish oil and fish protein led to reductions in TAG and cholesterol in serum and the liver, whereas sole intake of fish oil or fish protein decreased only TAG and cholesterol contents, respectively [13]. Dietary protein and its hydrolysates have been found to influence cholesterol metabolism in human and animals subjects $[14,15]$. Therefore, it might be expected that fish oil with added a protein or protein hydrolysates could reduce not only TAG contents but also cholesterol contents. In this study, we investigated the effects of a fish oil diet in combination with hemoglobin $(\mathrm{Hb})$ hydrolysates on serum and liver lipids contents of rats. We chose $\mathrm{Hb}$ hydrolyastes as the combination component because it demonstrated hypolipidemic effect superior to that of other protein hydrolysates [16]. The results herein demonstrate that functional foods and supplements containing fish oil could be developed with the addition of $\mathrm{Hb}$ hydrolysates.

\section{Materials and Methods}

\subsection{Materials}

Porcine $\mathrm{Hb}$ hydrolysates obtained from ILS Inc. (Ibaraki, Japan). Fish oil ( $>99.5 \%$ triacylglycerol) prepared from Bigeye tuna (Thunnus obesus) was provided by Yashima Shiyoji Co., Ltd (Shizuoka, Japan). The ingredients for the experimental diets were purchased from Oriental Yeast Co. (Tokyo, Japan). All other chemicals were obtained from commercial sources and were of reagent grade.

\subsection{Analysis of Fish Oil and Hemoglobin Hydrolysates}

The composition of fatty acids in soybean oil and fish oil were determined by analysis using a fused silica capillary column, Omegawax 250 (Supelco; Pennsylvania, USA) in a gas-liquid chromatography (GC) system (GC-14B, Shimadzu Co.; Kyoto, Japan) after methylation with sodium methoxide [17]. The injection and detection temperatures were $250^{\circ} \mathrm{C}$ and $260^{\circ} \mathrm{C}$, respectively. The initial column temperature of $120^{\circ} \mathrm{C}$ was increased to $240^{\circ} \mathrm{C}$ at a rate of $2^{\circ} \mathrm{C} / \mathrm{min}$. Fatty acid species was identified using the retention time of a fatty acid methyl ester standard solution (Supelco ${ }^{\circledR} 37$ Component FAME Mix, SigmaAldrich Japan Co. Ltd.; Tokyo, Japan).

The protein content in casein and $\mathrm{Hb}$ hydrolysates was determined the methods of Kjeldahl, with an N-to-protein conversion factor of 6.25 . The dietary proteins were hydrolyzed using $6 \mathrm{~N} \mathrm{HCl}$ at $110^{\circ} \mathrm{C}$ for 24 hours. The amino acid composition was determined by reversedphase high-performance liquid chromatography (HPLC) with UV detection after derivatization with phenylisothiocyanate [18]. The identification and quantitation of each amino acid was conducted using commercially available authentic standard mixtures. Iron in Hb hydrolysates was measured using an atomic absorption spectrometer (AA-6300; Shimadzu Co.) The molecular weight (MW) distribution was analyzed by gel permeation HPLC using TSKgel G3000SWXL (7.8 mm I.D. × $30 \mathrm{~cm}$ column, Tosoh Co., Tokyo, Japan) with UV detection (UV-8020 spectrophotometer, Tosoh Co.).

\subsection{Animal Experiments}

The experimental protocol was reviewed and approved by the Animal Ethics Committee of Kansai Medical University and followed the "Guide for the Care and Use of Experimental Animals" issued by the Prime Minister's Office of Japan. Male 5-week-old Wistar rats (Shimizu Laboratory Supplies Co., Ltd.; Kyoto, Japan) were kept in an air-conditioned room (temperature, $21^{\circ} \mathrm{C}-22^{\circ} \mathrm{C}$; humidity, 55\% - 65\%; lights on, 08:00-20:00), with free access to tap water and feed. Twenty-eight rats were divided into four dietary groups of seven rats each. One group was fed a casein and soybean oil-based semi-purified basal diet (AIN93G [Control] diet [19]) and the other three groups were fed the basal diet supplemented with $2 \%$ fish oil (FO group), $0.175 \% \mathrm{Hb}$ hydrolysates (HbH group), or $2 \%$ fish oil plus $0.175 \% \mathrm{Hb}$ hydrolysates $(\mathrm{FO} \times \mathrm{HbH}$ group) for 4 weeks. Table 1 shows the composition of the experimental diets prepared based on the AIN93G formulation [19]. The basal diet excluded iron citrate from the AIN93G diet; therefore, the iron content of the experimental diets was adjusted to 35 $\mathrm{mg} / \mathrm{kg}$ by supplemented with iron as iron citrate (Control and $\mathrm{FO}$ diets) or hemoglobin hydrolysates $(\mathrm{HbH}$ and $\mathrm{FO}$ $\times \mathrm{HbH}$ diets). At the end of the feeding periods, rats were weighed and sacrificed under pentobarbital (Nembutal ${ }^{\mathbb{B}}$, Dainippon Sumitomo Pharma Co., Ltd.; Osaka, Japan) anesthesia. Blood was collected from the abdominal aorta, and liver, small intestine, cecum, and abdominal WAT from the epididymis, mesentery, perinephria, and retroperitoneum were removed rapidly, weighed, rinsed with saline, and then frozen in liquid nitrogen, followed by storage at $-80^{\circ} \mathrm{C}$ until analysis. Serum was obtained by centrifugation at $2000 \times g$ for $15 \mathrm{~min}$ and subjected to serum biochemical tests. Feces were collected from each group every 24 hours for 7 days before being sacrificed, dried to a constant weight, and ground to a fine powder using a mill.

\subsection{Analysis of Serum, Liver, and Feces Components}

Serum aspartate aminotransferase (AST), alanine aminotransferase (ALT), TAG, cholesterol, phospholipid 
Table 1. Composition of the experimental diets.

\begin{tabular}{ccccc}
\hline \multirow{2}{*}{ Composition } & \multicolumn{5}{c}{ Dietary group } \\
\cline { 2 - 5 } & Control & FO & HbH & FO $\times \mathrm{HbH}$ \\
Soybean oil & 70 & 50 & 70 & 50 \\
Fish oil & - & 20 & - & 20 \\
Casein & 200 & 200 & 198.25 & 198.25 \\
Hb hydrolysates & - & - & 1.75 & 1.75 \\
Dextrinized corn starch & 132 & 132 & 132 & 132 \\
Corn starch & 397.486 & 397.486 & 397.486 & 397.486 \\
Sucrose & 99.965 & 99.965 & 100 & 100 \\
Cellulose & 50 & 50 & 50 & 50 \\
AIN93G mineral mixture & 35 & 35 & 35 & 35 \\
AIN93 vitamin mixture & 10 & 10 & 10 & 10 \\
Iron citrate & 0.035 & 0.035 & - & - \\
1-Cystine & 3 & 3 & 3 & 3 \\
Choline bitartrate & 2.5 & 2.5 & 2.5 & 2.5 \\
tert-Butylhydroquinone & 0.014 & 0.014 & 0.014 & 0.014 \\
\hline
\end{tabular}

*The iron content was $2 \mathrm{~g} / 100 \mathrm{~g}$ and protein content was $86.1 \mathrm{~g} / 100 \mathrm{~g}$. ${ }^{\dagger}$ The AIN93G mineral mixture excluded iron citrate but included sucrose. The iron content of the experimental diets was adjusted to $35 \mathrm{mg} / \mathrm{kg}$ by supplementing with iron as iron citrate (Control and FO diets) or $\mathrm{Hb}$ hydrolysates $(\mathrm{HbH}$ and $\mathrm{FO} \times \mathrm{HbH}$ diets). FO, fish oil; $\mathrm{Hb}$, hemoglobin; $\mathrm{HbH}, \mathrm{Hb}$ hydrolysates.

(PL), HDL-cholesterol, and non-HDL-cholesterol contents were measured in triplicate using an Olympus AU5431 automatic analyzer with AU regent (Beckman Coulter Inc.; California, USA).

Liver lipids were extracted in accordance with the method of Bligh and Dyer [20]. Liver PL content was measured by phosphorus analysis [21]. Liver TAG content was determined using an enzymatic assay kit (Triglyceride-E-Test Wako, Wako Pure Chemical Industries, Ltd.; Osaka, Japan). Liver cholesterol content was analyzed by GC using an SE-30 column (Shinwa Chemical Industries Ltd., Kyoto, Japan), with $5 \alpha$-cholestane as an internal standard.

Fecal fatty acids content was determined by the method of Van de Kamer et al. [22]. Fecal neutral steroids, i.e. the sum of cholesterol and coprostanol, content was determined by GC as described above, and fecal acidic steroids content was determined as $\mu$ moles $3 \alpha$ hydroxysteroid based on the molar extinction coefficient of NADH at $340 \mathrm{~nm}$ [23].

\subsection{Statistical Analysis}

Data are expressed as means \pm standard error of mean
(SEM). To determine the effects of dietary fatty acids and protein, data were analyzed using a two-way analysis of variance (ANOVA), and statistical comparisons in each group were made using Tukey-Kramer test; these were performed using StatView-J version 5.0 software (Abacus Concept, California, USA). Differences were considered significant at $p<0.05$.

\section{Results and Discussion}

Table 2 shows the fatty acid composition of soybean oil and fish oil. Fish oil had abundant $n-3$ PUFAs, such as EPA $(8.4 \%)$ and DHA $(30.0 \%)$, but the ratio of linoleic acid was low. Table 3 shows the amino acid composition of casein and $\mathrm{Hb}$ hydrolysates. In $\mathrm{Hb}$ hydrolysates, arginine, aspartic acid, glycine, histidine, leucine, and valine levels were high, whereas alanine, glutamic acid, and lysine levels were low compared with casein. Analysis of the MW of casein detected mostly bands at approximately $30 \mathrm{kDa}$, whereas the $\mathrm{MW}$ of $\mathrm{Hb}$ hydrolysates was $<3 \mathrm{kDa}$ (data not shown).

Table 4 shows the growth parameters and relative organ weights. No influence on growth parameters was observed in $\mathrm{FO}$ and $\mathrm{HbH}$ groups. Rats fed on diets containing $\mathrm{Hb}$ hydrolysates showed higher relative small intestine weights $(p=0.021)$, but the fatty acid composition was not affected. In addition, dietary $\mathrm{Hb}$ hydrolysates

Table 2. Fatty acid composition of dietary oils.

\begin{tabular}{|c|c|c|}
\hline & \multicolumn{2}{|c|}{ Dietary oil } \\
\hline & Soybean oil & Fish oil \\
\hline & \multicolumn{2}{|c|}{$\mathrm{wt} \%$} \\
\hline C14:0 & ND & 3.4 \\
\hline C16:0 & 10.8 & 18.7 \\
\hline C16:1 & ND & 5.3 \\
\hline C18:0 & 4.2 & 4.6 \\
\hline $\mathrm{C} 18: 1 n-9$ & 23.5 & 16.1 \\
\hline $\mathrm{C} 18: 1 n-7$ & 1.6 & 2.2 \\
\hline C18:2n-6 & 53.1 & 1.4 \\
\hline $\mathrm{C} 18: 3 n-3$ & 5.7 & 1.8 \\
\hline $\mathrm{C} 20: 1 n-9$ & ND & 2.7 \\
\hline C20:4n-6 & ND & 1.3 \\
\hline $\mathrm{C} 20: 5 n-3$ & ND & 8.4 \\
\hline $\mathrm{C} 22: 5 n-3$ & ND & 1.1 \\
\hline $\mathrm{C} 22: 6 n-3$ & ND & 30.0 \\
\hline Others & 1.1 & 3.1 \\
\hline
\end{tabular}

ND, not detected. 
Table 3. Amino acid composition of dietary proteins.

\begin{tabular}{ccc}
\hline & \multicolumn{2}{c}{ Dietary protein } \\
\cline { 2 - 3 } Casein & Hb hydrolysates \\
\hline Alanine & \multicolumn{2}{c}{$\mathrm{g} / 100 \mathrm{~g}$ protein } \\
Arginine & 8.67 & 3.79 \\
Aspartic acid & 5.47 & 13.07 \\
Glutamic acid & 5.90 & 15.74 \\
Glycine & 19.76 & 5.83 \\
Histidine & 2.03 & 5.68 \\
Isoleucine & 2.69 & 6.20 \\
Leucine & 3.22 & 0.98 \\
Lysine & 9.32 & 14.79 \\
Methionine & 7.03 & 2.94 \\
Phenylalanine & 2.98 & 0.85 \\
Proline & 5.79 & 8.77 \\
Serine & 4.25 & 2.10 \\
Threonine & 6.68 & 3.03 \\
Tyrosine & 3.60 & 4.35 \\
Valine & 5.96 & 1.31 \\
\hline
\end{tabular}

*Aspartic acid: Aspartic acid + Asparagine; ${ }^{\dagger}$ Glutamic acid: Glutamic acid + Glutamine.

decreased relative epididymal WAT weight compared with dietary casein alone. There were no significant differences in the relative weights of liver, cecum, mesentery WAT, perirenal and retroperitoneal WAT, and total WAT among the groups.

Table 5 shows the results of serum biochemical tests and liver lipids contents. AST levels were decreased in the $\mathrm{HbH}$ group compared with in the Control group. There were no differences the serum ALT levels among the groups. Previous studies suggested that fish oil and $\mathrm{Hb}$ hydrolysates affected serum and liver lipid contents in animal experiments $[4,5,16]$. In this study, the FO group, compared with the Control group, had decreased serum PL, TAG, liver TAG contents, but serum and liver cholesterol contents were not affected. In addition, the $\mathrm{HbH}$ group had lower serum and liver TAG and cholesterol contents than the Control group. Surprisingly, the combination of fish oil and $\mathrm{Hb}$ hydrolysates decreased serum and liver cholesterol contents, which was not found in the FO group. Serum and liver TAG contents were not altered in the $\mathrm{FO} \times \mathrm{HbH}$ group. The combination of fish oil and $\mathrm{Hb}$ hydrolysates did not have a synergistic effect, but instead it had independent effects on serum and liver cholesterol contents. Wergedahl et al. reported that the combination of fish oil and fish protein hydrolysates $(100 \mathrm{~g} / \mathrm{kg}$ diet) prepared from Salmon reduced plasma cholesterol contents, mainly by a reduction in HDL-cholesterol, whereas the liver cholesterol content was higher than rats fed diets containing fish oil and fish protein hydrolysates alone [24]. Hosomi et al. demonstrated that a diet containing fish oil supplemented with fish protein $(100 \mathrm{~g} / \mathrm{kg} \mathrm{diet})$ obtained from Alaska Pollock decreased serum and liver cholesterol contents compared with diets containing fish oil or fish protein alone [13]. In this study, the effects of decreased serum and liver cholesterol contents were documented with the FO diet supplemented with $1.75 \mathrm{~g} / \mathrm{kg} \mathrm{Hb}$ hydrolysates, but the effect was lower than that in other studies [13,24]. Therefore, $\mathrm{Hb}$ hydrolysates are an optimal food material that can be added to the hypocholesterolemic effect produced by fish oil.

Previous reports suggested that dietary fish oil decreases serum TAG and increases serum low-density lipoprotein (LDL)-cholesterol contents, but it did not lower serum total cholesterol [6]. The FO diet did not influence serum cholesterol, HDL-cholesterol, or nonHDL-cholesterol contents compared with the Control diet. The $\mathrm{FO} \times \mathrm{HbH}$ diet, compared with the Control diet, decreased serum HDL-cholesterol owing to the additive effect of both compounds, but not as a result of any synergistic effect. The non-HDL-cholesterol content in the $\mathrm{FO} \times \mathrm{HbH}$ group was significantly lower than that in the other three groups. Blood LDL-cholesterol content is a primary target of lipid-lowering therapy in hyperlipidemic patients [25]. However, blood non-HDL-cholesterol content may be a more relevant target for lipidlowering therapy because it contains all the lipids and lipoproteins such as LDL-cholesterol, intermediate-density lipoprotein, and very-low-density lipoprotein [26]. Indeed, previous meta-analyses have demonstrated that non-HDL-cholesterol content is a better predictor than LDL-cholesterol for future CVD risk [27,28]. In this study, the dietary combination of fish oil and $\mathrm{Hb}$ hydrolysates reduced serum non-HDL-cholesterol content, and, therefore, might beneficially affect the course of CVD. However, because rats have high amounts of circulating HDL particles and small amounts of circulating nonHDL particles, these findings did not contribute much to the non-HDL-cholesterol lowering effect of the FO $\times$ $\mathrm{HbH}$ diet, but the results could be of importance from a health benefit perspective.

Two major mechanisms have been proposed to explain the decreases in lipid contents in serum and liver that are associated with dietary oil and protein. One is an endogenous change in lipid metabolism, which is maintained through a balance of excretion, biosynthesis, storage, catabolism, and uptake; the other is an exogenous 
Table 4. Growth parameters and relative organ weights of rats fed experimental diets for 4 weeks.

\begin{tabular}{|c|c|c|c|c|c|c|c|}
\hline & \multicolumn{4}{|c|}{ Dietary group } & \multicolumn{3}{|c|}{ ANOVA ( $p$ values) } \\
\hline & Control & FO & $\mathrm{HbH}$ & $\mathrm{FO} \times \mathrm{HbH}$ & Fatty acid (F) & Protein $(\mathrm{P})$ & $\mathrm{F} \times \mathrm{P}$ \\
\hline \multicolumn{8}{|l|}{ Growth parameters } \\
\hline Initial BW (g) & $127 \pm 3$ & $126 \pm 2$ & $126 \pm 3$ & $127 \pm 1$ & 0.976 & 0.976 & 0.835 \\
\hline Final BW (g) & $320 \pm 7$ & $322 \pm 4$ & $314 \pm 4$ & $314 \pm 4$ & 0.837 & 0.151 & 0.837 \\
\hline BW gain (g/day) & $6.89 \pm 0.21$ & $6.98 \pm 0.16$ & $6.69 \pm 0.14$ & $6.68 \pm 0.10$ & 0.807 & 0.118 & 0.733 \\
\hline Energy intake (g/day) & $72.2 \pm 1.6$ & $72.4 \pm 1.8$ & $72.0 \pm 1.8$ & $72.3 \pm 1.4$ & 0.842 & 0.903 & 0.986 \\
\hline Food efficiency (g/kcal) & $0.096 \pm 0.003$ & $0.096 \pm 0.002$ & $0.093 \pm 0.002$ & $0.092 \pm 0.001$ & 0.931 & 0.139 & 0.746 \\
\hline \multicolumn{8}{|l|}{ Relative organ weights (g/100 g BW) } \\
\hline Liver & $3.78 \pm 0.11$ & $3.79 \pm 0.14$ & $3.86 \pm 0.08$ & $3.88 \pm 0.08$ & 0.912 & 0.426 & 0.961 \\
\hline Small intestine & $2.73 \pm 0.13$ & $2.73 \pm 0.15$ & $3.21 \pm 0.17$ & $2.92 \pm 0.09$ & 0.294 & 0.021 & 0.303 \\
\hline Cecum & $0.88 \pm 0.09$ & $0.95 \pm 0.08$ & $1.06 \pm 0.08$ & $0.89 \pm 0.05$ & 0.524 & 0.452 & 0.106 \\
\hline Epididymal WAT & $1.53 \pm 0.07$ & $1.53 \pm 0.05$ & $1.36 \pm 0.05$ & $1.41 \pm 0.03$ & 0.676 & 0.016 & 0.647 \\
\hline Mesentery WAT & $1.25 \pm 0.14$ & $1.38 \pm 0.12$ & $1.05 \pm 0.08$ & $1.28 \pm 0.12$ & 0.142 & 0.218 & 0.660 \\
\hline Perirenal and retroperitoneal WAT & $1.10 \pm 0.04$ & $1.14 \pm 0.05$ & $1.11 \pm 0.07$ & $1.15 \pm 0.04$ & 0.444 & 0.742 & 0.991 \\
\hline Total WAT ${ }^{*}$ & $3.88 \pm 0.24$ & $4.04 \pm 0.21$ & $3.53 \pm 0.12$ & $3.85 \pm 0.15$ & 0.208 & 0.155 & 0.678 \\
\hline
\end{tabular}

Data represent means \pm SEM $(n=7) .{ }^{*}$ Total WAT represents the sum of WAT weights from the epididymis, mesentery, perinephria, and retroperitoneum. BW, body weight; F, fatty acid; FO, fish oil; $\mathrm{HbH}$, Hb hydrolysates; P, protein; SEM, standard error of the mean; WAT, white adipose tissue.

Table 5. Serum biochemical tests and liver lipids contents of rats fed experimental diets for 4 weeks.

\begin{tabular}{|c|c|c|c|c|c|c|c|}
\hline & \multicolumn{4}{|c|}{ Dietary group } & \multicolumn{3}{|c|}{ ANOVA ( $p$ values) } \\
\hline & Control & FO & $\mathrm{HbH}$ & $\mathrm{FO} \times \mathrm{HbH}$ & Fatty acid (F) & Protein $(\mathrm{P})$ & $\mathrm{F} \times \mathrm{P}$ \\
\hline \multicolumn{8}{|l|}{ Serum component } \\
\hline AST (IU/L) & $90.9 \pm 1.3^{\mathrm{a}}$ & $83.7 \pm 3.0^{\mathrm{ab}}$ & $79.7 \pm 2.7^{\mathrm{b}}$ & $86.4 \pm 2.1^{\mathrm{ab}}$ & 0.929 & 0.091 & 0.008 \\
\hline ALT (IU/L) & $53.9 \pm 2.7$ & $49.3 \pm 2.5$ & $47.1 \pm 1.3$ & $47.4 \pm 0.9$ & 0.295 & 0.430 & 0.237 \\
\hline PL (mg/dL) & $146 \pm 7^{\mathrm{a}}$ & $118 \pm 5^{\mathrm{b}}$ & $113 \pm 3^{b}$ & $103 \pm 3^{b}$ & 0.001 & $<0.001$ & 0.088 \\
\hline $\mathrm{TAG}(\mathrm{mg} / \mathrm{dL})$ & $33.3 \pm 1.7^{\mathrm{a}}$ & $22.9 \pm 1.0^{\mathrm{b}}$ & $24.7 \pm 2.2^{\mathrm{b}}$ & $26.3 \pm 2.3^{\mathrm{ab}}$ & 0.027 & 0.182 & 0.004 \\
\hline Cholesterol (mg/dL) & $78.1 \pm 2.7^{\mathrm{a}}$ & $73.6 \pm 1.4^{\mathrm{a}}$ & $58.7 \pm 2.2^{\mathrm{b}}$ & $51.6 \pm 1.9^{\mathrm{b}}$ & 0.011 & $<0.001$ & 0.552 \\
\hline HDL-cholesterol (mg/dL) & $52.7 \pm 3.4^{\mathrm{a}}$ & $45.3 \pm 1.9^{\mathrm{a}}$ & $35.9 \pm 1.6^{\mathrm{b}}$ & $35.3 \pm 1.6^{\mathrm{b}}$ & 0.091 & $<0.001$ & 0.145 \\
\hline Non-HDL-cholesterol (mg/dL) & $25.4 \pm 1.8^{\mathrm{a}}$ & $28.3 \pm 1.7^{\mathrm{a}}$ & $22.9 \pm 0.8^{\mathrm{a}}$ & $16.3 \pm 1.1^{\mathrm{b}}$ & 0.199 & $<0.001$ & 0.003 \\
\hline \multicolumn{8}{|l|}{ Liver lipid (mg/g liver) } \\
\hline PL & $19.8 \pm 1.1^{\mathrm{c}}$ & $21.6 \pm 0.6^{\mathrm{bc}}$ & $24.7 \pm 0.6^{\mathrm{a}}$ & $23.6 \pm 0.8^{\mathrm{ab}}$ & 0.683 & 0.002 & 0.086 \\
\hline TAG & $47.0 \pm 6.3^{\mathrm{a}}$ & $28.1 \pm 1.9^{b}$ & $20.1 \pm 5.0^{\mathrm{b}}$ & $26.1 \pm 2.7^{\mathrm{b}}$ & 0.151 & 0.003 & 0.009 \\
\hline Cholesterol & $4.17 \pm 0.50^{\mathrm{a}}$ & $3.34 \pm 0.20^{\mathrm{ab}}$ & $2.44 \pm 0.09^{\mathrm{b}}$ & $2.94 \pm 0.14^{\mathrm{b}}$ & 0.550 & 0.001 & 0.023 \\
\hline
\end{tabular}

Data represent means \pm SEM $(n=7)$. Means in the same row not sharing a common superscript letter differ significantly $(p<0.05)$. ALT, alanine aminotransferase; AST, aspartate aminotransferase, F, fatty acid; FO, fish oil; HbH, Hb hydrolysates; HDL, high-density lipoprotein; P, protein; PL, phospholipid; SEM, standard error of the mean; TAG, triacylglycerol. 
Table 6. Fecal dry weight, fatty acids, neutral steroids, acidic steroids, and total steroids in rats fed the experimental diets for 4 weeks.

\begin{tabular}{|c|c|c|c|c|c|c|c|}
\hline & \multicolumn{4}{|c|}{ Dietary group } & \multicolumn{3}{|c|}{ ANOVA ( $p$ values) } \\
\hline & Control & FO & $\mathrm{HbH}$ & $\mathrm{FO} \times \mathrm{HbH}$ & Fatty acid (F) & Protein $(\mathrm{P})$ & $\mathrm{F} \times \mathrm{P}$ \\
\hline Dry weight (g/day) & $38.9 \pm 2.1^{\mathrm{a}}$ & $22.2 \pm 1.8^{\mathrm{b}}$ & $33.9 \pm 1.4^{\mathrm{a}}$ & $40.0 \pm 3.1^{\mathrm{a}}$ & 0.024 & 0.008 & $<0.001$ \\
\hline Fatty acids (mg/day) & $4.38 \pm 0.44^{\mathrm{b}}$ & $5.51 \pm 0.59^{\mathrm{b}}$ & $8.02 \pm 0.38^{\mathrm{ab}}$ & $10.70 \pm 1.48^{\mathrm{a}}$ & 0.049 & $<0.001$ & 0.405 \\
\hline Neutral steroids ${ }^{*}(\mu \mathrm{mol} /$ day $)$ & $87.3 \pm 9.7^{b}$ & $133.8 \pm 10.9^{\mathrm{a}}$ & $97.9 \pm 6.3^{\mathrm{b}}$ & $92.1 \pm 4.6^{\mathrm{b}}$ & 0.021 & 0.073 & 0.004 \\
\hline Cholesterol ( $\mu \mathrm{mol} /$ day $)$ & $18.9 \pm 3.2^{\mathrm{b}}$ & $27.0 \pm 1.8^{\mathrm{ab}}$ & $26.9 \pm 2.1^{\mathrm{ab}}$ & $28.0 \pm 1.5^{\mathrm{a}}$ & 0.053 & 0.057 & 0.129 \\
\hline Coprostanol ( $\mu \mathrm{mol} /$ day $)$ & $68.4 \pm 7.0^{\mathrm{b}}$ & $106.8 \pm 9.2^{\mathrm{a}}$ & $71.0 \pm 4.3^{\mathrm{b}}$ & $64.2 \pm 3.3^{\mathrm{b}}$ & 0.021 & 0.005 & 0.002 \\
\hline Acidic steroids ( $\mu \mathrm{mol} / \mathrm{day})$ & $40.0 \pm 2.4^{\mathrm{c}}$ & $57.4 \pm 3.4^{\mathrm{b}}$ & $66.4 \pm 4.6^{\mathrm{b}}$ & $83.4 \pm 4.0^{\mathrm{a}}$ & $<0.001$ & $<0.001$ & 0.959 \\
\hline Total steroids ${ }^{\dagger}(\mu \mathrm{mol} /$ day $)$ & $127 \pm 11^{\mathrm{b}}$ & $183 \pm 10^{\mathrm{a}}$ & $164 \pm 8^{\mathrm{a}}$ & $176 \pm 6^{\mathrm{a}}$ & 0.001 & 0.111 & 0.021 \\
\hline
\end{tabular}

Data represent means \pm SEM $(n=7)$. Means in the same row not sharing a common superscript letter differ significantly $(p<0.05)$. ${ }^{*}$ Neutral steroids represent the sum of cholesterol and coprostanol. ${ }^{\dagger}$ Total steroids represent the sum of neutral and acidic steroids. F, fatty acid; FO, fish oil; HbH, Hb hydrolysates; P, protein; SEM, standard error of the mean.

increase in the excretion of fatty acid and steroids, including neutral and acidic [29]. In first mechanism, many researchers have already suggested that fish oil enhances fatty acid $\beta$-oxidation, suppresses fatty acid synthesis, and stimulates the thermogenic activity in brown adipose tissue [30,31]. However, few studies have evaluated the effect of dietary fish oil on fecal lipid excretion. To examine the effect of dietary fish oil and $\mathrm{Hb}$ hydrolysates on exogenous changes, this study evaluated the excretion of fecal fatty acids, neutral steroids, and acidic steroids. Table 6 shows the fecal weight and lipids contents. Fecal dry weight in the FO group was significantly lower than that in the other groups. The $\mathrm{FO} \times \mathrm{HbH}$ diet enhanced the excretion of fecal fatty acids compared with the Control and $\mathrm{FO}$ diets, mainly owing to presence of $\mathrm{Hb}$ hydrolysates $(p<0.001)$. Serum and liver TAG contents in rats fed diets containing $\mathrm{Hb}$ hydrolyasates could be attributable to the enhancement of fatty acid excretion in feces. In addition, dietary fish oil did not alter the excretion of fecal fatty acids, so the reduction in serum and liver TAG by fish oil might enhance endogenous fatty acid oxidation, as described in previous reports [30]. Fecal output of neutral steroids (cholesterol and coprostanol) was significantly higher in the FO group than in all other groups. Excretion of fecal acidic steroids was associated with dietary fish oil and $\mathrm{Hb}$ hydrolysates $(p<0.001$ and $p<0.001$, respectively), and specifically $\mathrm{Hb}$ hydrolysates-containing diets $(\mathrm{HbH}$ and $\mathrm{FO} \times \mathrm{HbH})$ had more strongly increased excretion of fecal acidic steroids compared with the fish oil-containing diet. The $\mathrm{FO}, \mathrm{HbH}$, and $\mathrm{FO} \times \mathrm{HbH}$ diets enhanced excretion of fecal total steroids (neutral and acidic steroids) compared with the Control diet. Nagata et al. found that the degree of serum cholesterol content lowering depended on the extent fecal steroids excretion [32]. In this study, total steroids in feces were higher in rats fed the FO diet than in rats fed on the Control diet; however, the FO group did not exhibit alterations in serum and liver cholesterol contents. This cause is not understood at present. Cholesterol $7 \alpha$-hydroxylase, the rate-limiting enzyme in the conversion of cholesterol to bile acids, is mainly regulated by the feedback inhibition by reabsorbed bile acids [33]. The combination of fish oil and $\mathrm{Hb}$ hydrolysates strongly affected the excretion of fecal acidic steroids, and thus could be reduce serum and liver cholesterol contents.

\section{Conclusion}

The important finding in this study was that the fish oil diet decreased serum and liver TAG contents, while the combination of fish oil and $\mathrm{Hb}$ hydrolysates decreased serum TAG, cholesterol, and non-HDL-cholesterol contents in part owing to enhanced excretion of acidic steroids. The results show that the dietary combination fish oil and $\mathrm{Hb}$ hydrolysates may have beneficial effects on the reduction of CVD risk as compared with a diet containing fish oil alone.

\section{Acknowledgements}

We thank Ren Otsuka of Kansai University for support with animal care and lipid analyses.

\section{REFERENCES}

[1] K. He, Y. Song, M. L. Daviglus, K. Liu, L. Van Horn, A. R. Dyer and P. Greenland, "Accumulated Evidence on Fish Consumption and Coronary Heart Disease Mortality: A Meta-Analysis of Cohort Studies," Circulation, Vol. 109, No. 22, 2004, pp. 2705-2711. doi:10.1161/01.CIR.0000132503.19410.6B

[2] J. Dyerberg, H. O. Bang, E. Stoffersen, S. Moncada and J. R. Vane, "Eicosapentaenoic Acid and Prevention of Thrombosis and Atherosclerosis?" Lancet, Vol. 2, No. 
8081,1978, pp. 117-119. doi:10.1016/S0140-6736(78)91505-2

[3] F. B. Hu, L. Bronner, W. C. Willett, M. J. Stampfer, K. M. Rexrode, C. M. Albert, D. Hunter and J. E. Manson, "Fish and Omega-3 Fatty Acid Intake and Risk of Coronary Heart Disease in Women," The Journal of the American Medical Association, Vol. 287, No. 14, 2002, pp. 1815-1821.doi:10.1001/jama.287.14.1815

[4] R. K. Berge, L. Madsen, H. Vaagenes, K. J. Tronstad, M. Göttlicher and A. C. Rustan, "In Contrast with Docosahexaenoic Acid, Eicosapentaenoic Acid and Hypolipidaemic Derivatives Decrease Hepatic Synthesis and Secretion of Triacylglycerol by Decreased Diacylglycerol Acyltransferase Activity and Stimulation of Fatty Acid Oxidation," Biochemical Journal, Vol. 343, No. 1, 1999, pp. 191-197.

[5] Y. Adkins and D. S. Kelley, "Mechanisms Underlying the Cardioprotective Effects of Omega-3 Polyunsaturated Fatty Acids," The Journal of Nutritional Biochemistry, Vol. 21, No. 9, 2010, pp. 781-792.

doi:10.1016/j.jnutbio.2009.12.004

[6] E. M. Balk, A. H. Lichtenstein, M. Chung, B. Kupelnick, P. Chew and J. Lau, "Effects of Omega-3 Fatty Acids on Serum Markers of Cardiovascular Disease Risk: A Systematic Review," Atherosclerosis, Vol. 189, No. 1, 2006, pp. 19-30. doi:10.1016/j.atherosclerosis.2006.02.012

[7] Z. S. Saify, F. Ahmed, S. Akhtar, S. Siddiqui, M. Arif, S. A. Hussain and N. Mushtaq, "Biochemical Studies on Marine Fish Oil Part-I: Effects of Fish Oil and Lipid Lowering Drugs on HDL/LDL Cholesterol Levels," Pakistan Journal of Pharmaceutical Sciences, Vol. 16, No. 2, 2003, pp. 1-8.

[8] V. Nambi and C. M. Ballantyne, "Combination Therapy with Statins and Omega-3 Fatty Acids," American Journal of Cardiology, Vol. 98, No. 4A, 2006, pp. 34i-38i. doi:10.1016/j.amjcard.2005.12.025

[9] T. Ide, D. D. Hong, P. Ranasinghe, Y. Takahashi, M. Kushiro and M. Sugano, "Interaction of Dietary Fat Types and Sesamin on Hepatic Fatty Acid Oxidation in Rats," Biochimica et Biophysica Acta, Vol. 1682, No. 1-3, 2004, pp. 80-91. doi:10.1016/j.bbalip.2004.02.001

[10] T. Yanagita, Y. M. Wang, K. Nagao, Y. Ujino and N. Inoue, "Conjugated Linoleic Acid-Induced Fatty Liver Can Be Attenuated by Combination with Docosahexaenoic Acid in C57BL/6N Mice," Journal of Agricultural and Food Chemistry, Vol. 53, No. 24, 2005, pp. 96299633. doi:10.1021/jf052203i

[11] H. Maeda, M. Hosokawa, T. Sashima and K. Miyashita, "Dietary Combination of Fucoxanthin and Fish Oil Attenuates the Weight Gain of White Adipose Tissue and Decreases Blood Glucose in Obese/Diabetic KK-Ay Mice," Journal of Agricultural and Food Chemistry, Vol. 55, No. 19, 2007, pp. 7701-7706. doi:10.1021/jf071569n

[12] N. Mikami, M. Hosokawa and K. Miyashita, "Dietary Combination of Fish Oil and Taurine Decreases Fat Accumulation and Ameliorates Blood Glucose Levels in Type 2 Diabetic/Obese KK-A(y) Mice," Journal of Food Science, Vol. 77, No. 6, 2012, pp. H114-H120. doi:10.1111/j.1750-3841.2012.02687.x
[13] R. Hosomi, K. Fukunaga, H. Arai, S. Kanda, T. Nishiyama and M. Yoshida, "Effect of Combination of Dietary Fish Protein and Fish Oil on Lipid Metabolism in Rats," Journal of Food Science and Technology, Vol. 50, No. 2, 2013, pp. 266-274. doi:10.1007/s13197-011-0343-y

[14] C. Brandsch, A. Shukla, F. Hirche, G. I. Stangl and K. Eder, "Effect of Proteins from Beef, Pork, and Turkey Meat on Plasma and Liver Lipids of Rats Compared with Casein and Soy Protein," Nutrition, Vol. 22, No. 11-12, 2006, pp. 1162-1170. doi:10.1016/j.nut.2006.06.009

[15] R. Hosomi, K. Fukunaga, H. Arai, S. Kanda, T. Nishiyama and M. Yoshida, "Fish Protein Decreases Serum Cholesterol in Rats by Inhibition of Cholesterol and Bile Acid Absorption," Journal of Food Science, Vol. 76, No. 4, 2011, pp. H116-H121. doi:10.1111/j.1750-3841.2011.02130.x

[16] K. Kagawa, H. Matsutaka, C. Fukuhama, Y. Watanabe and H. Fujino, "Globin Digest, Acidic Protease Hydrolysate, Inhibits Dietary Hypertriglyceridemia and ValVal-Tyr-Pro, One of Its Constituents, Possesses Most Superior Effect," Life Sciences, Vol. 58, No. 20, 1996, pp. 1745-1755. doi:10.1016/0024-3205(96)00156-7

[17] A. F. Prevot and F. X. Mordret, "Utilisation des Colonnes Capillaries de Verre Pour 1'Analyse des Corps Gras par Chromotographie en Phase Gazeuse," Revue Francaise des Corps Gras, Vol. 23, 1976, pp. 409-423.

[18] J. A. White, R. J. Hart and J. C. Fry, "An Evaluation of the Waters Pico-Tag System for the Amino-Acid Analysis of Food Materials," The Journal of Automatic Chemistry, Vol. 8, No. 4, 1986, pp. 170-177. doi: $10.1155 / \mathrm{S} 1463924686000330$

[19] P. G. Reeves, F. H. Nielsen and G. C. Fahey, “AIN-93 Purified Diets for Laboratory Rodents: Final Report of the American Institute of Nutrition Ad Hoc Writing Committee on the Reformulation of the AIN-76A Rodent Diet," The Journal of Nutrition, Vol. 123, No. 11, 1993, pp. 1939-1951.

[20] E. Bligh, and W. J. Dyer, "A Rapid Method of Total Lipid Extraction and Purification," Canadian Journal of Biochemistry and Physiology, Vol. 37, No. 8, 1959, pp. 911-917.

[21] G. Rouser, S. Fkeischer and A. Yamamoto, "Two Dimensional then Layer Chromatographic Separation of Polar Lipids and Determination of Phospholipids by Phosphorus Analysis of Spots," Lipids, Vol. 5, No. 5, 1970, pp. 494-496.

[22] J. H. Van de Kamer, H. Ten Bokkel Huinink and H. A. Weyers, "Rapid Method for the Determination of Fat in Feces," The Journal of Biological Chemistry, Vol. 177, No. 1, 1949, pp. 347-355.

[23] A. Bruusgaard, H. Sorensen, C. C. Gilhuus-Moe and B. A. Skålhegg, "Bile Acid Determination with Different Preparations of 3Alpha-Hydroxysteroid Dehydrogenase," Clinica Chimica Acta, Vol. 77, No. 3, 1977, pp. 387-389. doi:10.1016/0009-8981(77)90245-5

[24] H. Wergedahl, O. A. Gudbrandsen, T. H. Røst and R. K. Berge, "Combination of Fish Oil and Fish Protein Hydrolysate Reduces the Plasma Cholesterol Level with a Concurrent Increase in Hepatic Cholesterol Level in 
High-Fat-Fed Wistar Rats," Nutrition, Vol. 25, No. 1, 2009, pp. 98-104. doi:10.1016/j.nut.2008.07.005

[25] National Cholesterol Education Program (NCEP) Expert Panel on Detection, Evaluation, and Treatment of High Blood Cholesterol in Adults (Adult Treatment Panel III), "Third Report of the National Cholesterol Education Program (NCEP) Expert Panel on Detection, Evaluation, and Treatment of High Blood Cholesterol in Adults (Adult Treatment Panel III) Final Report," Circulation, Vol. 106, No. 25, 2002, pp. 3143-3421.

[26] J.S. Rana, S. M. Boekholdt, J. J. Kastelein and P. K. Shah, "The Role of Non-HDL Cholesterol in Risk Stratification for Coronary Artery Disease," Current Atherosclerosis Reports, Vol. 14, No. 2, 2012, pp. 130-134. doi:10.1007/s11883-011-0224-x

[27] S. M. Boekholdt, B. J. Arsenault, S. Mora, T. R. Pedersen, J. C. LaRosa, P. J. Nestel, R. J. Simes, P. Durrington, G. A. Hitman, K. M. Welch, D. A. DeMicco, A. H. Zwinderman, M. B. Clearfield, J. R. Downs, A. M. Tonkin, H. M. Colhoun, A. M. Gotto Jr., P. M. Ridker and J. J. Kastelein, "Association of LDL Cholesterol, Non-HDL Cholesterol, and Apolipoprotein B Levels with Risk of Cardiovascular Events among Patients Treated with Statins: A Meta-Analysis," The Journal of the American Medical Association, Vol. 307, No. 12, 2012, pp. 13021309. doi:10.1001/jama.2012.366

[28] A. D. Sniderman, K. Williams, J. H. Contois, H. M. Monroe, M. J. McQueen, J. de Graaf and C. D. Furberg, "A Meta-Analysis of Low-Density Lipoprotein Cholesterol, Non-High-Density Lipoprotein Cholesterol, and Apolipoprotein B as Markers of Cardiovascular Risk," Circulation: Cardiovascular Quality and Outcomes, Vol.
4, No. 3, 2011, pp. 337-345. doi:10.1161/CIRCOUTCOMES.110.959247

[29] Y. Nagata, N. Ishiwaki and M. Sugano, "Studies on the Mechanism of Antihypercholesterolemic Action of Soy Protein and Soy Protein-Type Amino Acid Mixtures in Relation to the Casein Counterparts in Rats," The Journal of Nutrition, Vol. 112, No. 8, 1982, pp. 1614-1625.

[30] H. Oudart, R. Groscolas, C. Calgari, M. Nibbelink, C. Leray, Y. Le Maho and A Malan, "Brown Fat Thermogenesis in Rats Fed High-Fat Diets Enriched with n-3 Polyunsaturated Fatty Acids," International Journal of Obesity, Vol. 21, No. 11, 1997, pp. 955-962.

[31] B. Ren, A. P. Thelen, J. M. Peters, F. J. Gonzalez and D. B. Jump, "Polyunsaturated Fatty Acid Suppression of Hepatic Fatty Acid Synthase and S14 Gene Expression Does Not Require Peroxisome Proliferator-Activated Receptor Alpha," The Journal of Biological Chemistry, Vol. 272, No. 43, 1997, pp. 26827-26832. doi:10.1074/jbc.272.43.26827

[32] Y. Nagata, K. Tanaka and M. Sugano, "Serum and Liver Cholesterol Levels of Rats and Mice Fed Soy-Bean Protein or Casein," Journal of Nutritional Science and Vitaminology, Vol. 27, No. 6, 1981, pp. 583-593. doi:10.3177/jnsv.27.583

[33] B. Goodwin, S. A. Jones, R. R. Price, M. A. Watson, D. D. McKee, L. B. Moore, C. Galardi, J. G. Wilson, M. C. Lewis, M. E. Roth, P. R. Maloney, T. M. Willson and S. A. Kliewer, "A Regulatory Cascade of the Nuclear Receptors FXR, SHP-1, and LRH-1 Represses Bile Acid Biosynthesis," Molecular Cell, Vol. 6, No. 3, 2000, pp. 517-526. doi:10.1016/S1097-2765(00)00051-4. 